The $5^{\text {th }}$ International Conference on Family Business and Entrepreneurship

\title{
IMPACTS OF MACROECONOMICS FACTORS TOWARD IDX COMPOSITE AND IDXFINANCE DURING COVID-19 PANDEMIC
}

\author{
M S J Aurelia ${ }^{1}$, R Febrianti², E S Nugraha ${ }^{3^{*}}$ \\ ${ }^{1,2,3}$ Faculty of Business, President University, \\ Corresponding author: edwin.nugraha@president.ac.id
}

\begin{abstract}
:
Macroeconomics is the branch of economy that deals with activity, structure, behaviour and decision making of economy as a whole. IDX Composite and IDX Finance are stock market indices used by Indonesia Stock Exchange, unfortunately, relationship between macroeconomics and IDX composite and IDX finance during COVID-19 period in Indonesia is still poorly understood. This research aimed to investigate the impacts of macroeconomics factor included Inflation Rate, Bank Indonesia rate (BI Rate), the exchange rate on IDR, and monthly new cases of COVID-19 in Indonesia on IDX Composite and IDXFINANCE, respectively. The analysis was using multiple linear regression method. The result indicated that BI Rate negatively significantly impacted both IDX Composite and IDXFINANCE. While, Indonesian inflation and USD to IDR exchange rate, gave significant impact on IDX Composite, consecutively positively and negatively. Partial test indicated that COVID-19 monthly cases in Indonesia did not impact both IDX Composite and IDXFINCANCE. In addition, Indonesian inflation and USD to IDR exchange rate also did not impact IDXFINANCE. Overall test illustrated that all of the mentioned macroeconomics variables impacted both IDX Composite and IDXFINANCE. This research is expected to help investors and traders in making futures investment decision.
\end{abstract}

Keywords: IDX Composite, IDXFINANCE, COVID-19, BI Rate, Inflation, Exchange Rate

\section{Introduction}

According to Parkin (2012), macroeconomics is the study about national and global economics' performance, which concern is about the overall economic performance (Parkin, M., 2012). Macroeconomics is the branch of the economy that deals with the activity, structure, behavior and decision making of the economy as a whole. Several aspects included as macroeconomics such as inflation rate, BI Rate, exchange rate, and many more. Since macroeconomics is about overall economic performance, stock market is included as well. In Indonesia, there are many types of stock market indices, for examples are IDX (Indonesia Stock Exchange) Composite or well-known as IHSG (Indeks Harga Saham Gabungan) and IDX (Indonesia Stock Exchange) FINANCE.

Stock market is in accordance with the high return high risk theory. Stock market is full of volatility, which requires both investor and trader to beware in analyzing and deciding to invest or trade in a company. One of the most important aspects in analyzing the current stock market condition is by looking at the IDX Composite. According to IDX, IDX Composite or IHSG is an overall index which measures all of the stock prices listed in IDX or BEI (Bursa Efek Indonesia), both as the main board and development board (Bursa Efek Indonesia, 2021).

Other than the index of the whole total listed companies, one of the most interesting index and sector is 
finance, also known as IDXFINANCE. According to the published factsheet index by IDX (Bursa Efek Indonesia, 2021), IDXFINANCE excels all of the other sectors, even IDX Composite, LQ45, and IDX30, in terms of the return. In the period of 2009 to 2019, IDXFINANCE gave a return of 349.92\%, in the past 5 (five) years IDXFINANCE gave a return of $85.15 \%$, and $15.22 \%$ for the past year.

Unfortunately, a sudden COVID-19 pandemic strikes almost all countries in the world, which gave a big impact on the stock market. In the year of 2019, IDX Composite price was usually on the level of prices around upper 5,000.00 and lower to upper 6,000.00, the lowest price was on May, 17th 2019 where the price hit 5,826.87. The IDX Composite started to hit a lower price from last year's lowest since February, 24th 2020 (Yahoo Finance, 2021), where at that time COVID-19 had already started spreading outside Indonesia. Even worse, since the first COVID-19 two-case in Indonesia in early March (Nuraini, 2020), on March 23rd and 24th 2020, IDX Composite hit the pit bottom price at 3,989.52 and 3,967.63, which that price of 3,000.00 never occurring again since 2012. Other than COVID-19 new cases, other macroeconomics factors that have been utilized in analyzing the impact on stock market index are inflation, BI rate and USD to IDR exchange rate.

Regarding the previous study, several research have been conducted. Megawati et al., 2018 has demonstrated the impact of BI rate, inflation and exchange rate on IDX Composite from Quarter I 2019 to Quarter IV 2016 (Megawati \& Salim, 2018). By utilizing multiple linear regression as the method, the authors obtained that exchange rate affected IDX Composite positively and significantly. Thus the authors also obtained that inflation and BI rate gave no significant impact toward IDX Composite. Other older research was conducted by Ilham et al., 2019 to determine the relationship between BI rate and IDX Composite from 2006 to 2015, which resulted in having a significant impact on IDX Composite (Ilham \& Nyoman, 2019)

Albeit there have been many studies on the impact of macroeconomics factors toward IDX Composite, there is scarcely any study that mentioned the impact of the macroeconomics on IDXFINANCE. On the other hand, there is also scarcely any research that studies on the impact of COVID-19 monthly cases, specifically in Indonesia, on both IDX Composite and IDXFINACE. Therefore, the research on macroeconomics impacts on IDX Composite and IDXFINANCE is scarcely being updated to the period when the COVID19 occurs. The explanation mentioned shows the importance of this research, moreover since IDX Composite is the most important stock market index in Indonesia, also IDXFINANCE is stock market sectoral index that gave the highest return among other sectors.

This research aimed to obtain the impact of macroeconomics factors, specifically USD to IDR exchange rate, Indonesian inflation, BI rate, and COVID-19 monthly cases toward IHSG (Index Harga Saham Gabungan) or IDX Composite and also IDXFINANCE. The limitation are on the macroeconomics factors and stock indices, also in the period of study which used March 2020, when the first COVID-19 case occurred in Indonesia, up to June 2021. This research followed quantitative research with multiple linear regression as the method. In which, the result of the research will be helpful for investors and traders to analyze the indices according to the macroeconomics.

\section{Literature Review}

Macroeconomic factors can influence the monthly activities of a company, Business decisions taken by investors need to consider predictions of future macroeconomic conditions (Kewal, 2012). The economic state of the country is one of the factors that can affect the activities of people living in the country (Nurdin, et, all., 2020). Many factors of macroeconomics can influence the rise and fall of a stock. The following is an explanation of the macroeconomic factors that we will use as response variables in this study:

\section{Inflation Rate}

Inflation is one of the important economic indicators, the rate of change is always tried to be low and stable. If inflation becomes high, it means that the tendency to continuously increase the price level of goods and services will weaken people's purchasing power which will have an effect on decreasing the country's income (Kewal, 2012). High inflation rates are usually related with economic conditions that are too declining, in the sense that economic conditions experience demand for products that exceed their product supply capacity, so prices tend to increase. If the amount of investment is reduced, this will cause national income to decline, which is an illustration of economic growth which will affect the stability of the activities of an economy, namely the wheels of development. High inflation may cut back the amount of real financial gain that investors get from their investments. 


\section{Exchange Rate USD to IDR}

The exchange rate is a value that indicates the amount of domestic currency needed to get foreign currency (other countries). Movements or changes in exchange rates can be influenced by various factors, including fundamental factors. Fundamental factors are reflected in macroeconomic variables, such as the rate of inflation, economic growth, and developments in exports and imports. The exchange rate is one of the macroeconomic variables that also affect stock price volatility.

\section{BI Rate}

The BI Rate is something that describes the attitude of the policies set by Bank Indonesia. The present value of the company's cash flow is influenced by the value of interest rates that are too high, it will reduce the opportunities for people who want to invest. There was a downward trend in the SBI interest rate accompanied by an increase in the IDX Composite. A monetary contraction that encourages an increase in interest rates can increase the cost of capital for the company. In addition, an Rising interest rates make the returns on deposits and bonds more attractive, which is why many capital market investors are rearranging their stock portfolios. Higher sales and lower demand will lower stock prices and vice versa.

\section{Capital Market}

In general, capital market is defined as a market for buying and selling various financial instruments or long-term securities, either in the form of debt or using capital, some of which are issued by governments, public authorities or private companies (Kewal, 2012). Composite Stock Price Index (CSPI) is a value used to measure the performance of stocks listed on a stock exchange. This index uses all companies as a component of the calculation of the capital index. In capital markets, an index serves several functions, including a market trend index, an income level index, and a benchmark for portfolio or mutual fund performance. This capital market indicator can fluctuate in line with changes in existing macroeconomic assumptions. Fluctuations that occur in the capital market will be related to changes that occur in various macroeconomic variables (Nurdin, et, all., 2020). The capital market performance will react to macroeconomic changes such as changes in exchange rates, interest rates, and inflation. Along with capital market indices, macroeconomic and foreign exchange indices also fluctuate, so investors should be able to understand the behavioral patterns of price movements and the value of stocks and the IDX summary of internal and external factors in a country that may affect the capital market before investing.

\section{Stock Index}

A stock index is a statistical indicator that reflects the overall price movement of a selected group of stocks based on certain criteria and methodologies and is regularly evaluated (Kewal, 2012). The objectives/benefits of stock indices include measuring market sentiment used as passive investment products, such as indexed mutual funds, indexed ETFs and derivatives, benchmarks for active portfolios, proxies for measuring and modelling return on investment, systematic risk, and risk-adjusted performance and proxy for asset class on asset allocation.

\section{IDXFINANCE}

IDXFINANCE is an index that measures the movement of prices of all stocks in the main tables and tables of the dynamics of the financial sector, refers to the IDX Industrial Classification (IDX-IC). IDXFINANCE was first launched on January 25, 2021. IDXFINANCE implements market capitalization weighted as its methodology, in formula of:

$$
\text { Index }=\frac{\sum_{i=1}^{n} \text { MarketCap }_{i}}{\text { BaseMarketCap }} \times 1000
$$

Base market cap is the total price of the company's shares is the price that must be paid to buy the entire company and market cap is the aggregate market value of a company, since it is IDXFINANCE, only financial sector company counted.

\section{IDX Composite}

The IDX Composite is an index that measures the price movement of all stocks listed on the Main Market and the Development Board of the Indonesian Stock Exchange. The date of the first launch was April 4, 
1983 , as an indicator of the price movement of the BEJ stock. Includes price movements for all common and preferred shares listed on IDX. The base date for calculating the IDX Composite was August 10, 1982. On that day, the index was set to a base value of 100 and the number of shares listed at that time was 13 shares. The highest intraday position ever achieved by the IDX Composite was 6,693.47 points recorded on February 20, 2018. The highest closing position ever reached was 6,689.29 points the day before. IDX Composite implements market capitalization weighted as its methodology, in formula of:

$$
\text { Index }=\frac{\sigma_{i=1}^{n} \text { MarketCap }_{i}}{\text { BaseMarketCap }} \times 100
$$

Previous research found that the inflation rate, SBI interest rate and GDP growth did not have a significant effect on the IDX Composite, while the rupiah exchange rate had a negative and significant effect on the IDX Composite (Kewal, 2012).

Meanwhile, based on the results of testing by Oktarina, D. 2015 revealed that several global stock indices and economic indicators, namely the Dow Jones Industrial Average Index, Nikkei 225 index, Shanghai Composite Index, FTSE 100 index, world oil prices, world gold prices, Rupiah exchange rate against the US Dollar (IDR/USD), interest rates (BI Rate), and inflation, together affect the IDX Composite (Oktarina, 2016).

Furthermore, in research conducted by Lukisto, J., and Anastasia, N. 2014 using the multiple linear regression method with the regression equation that has been formed, together inflation, SBI interest rates, exchange rates (Rupiah to Dollars), and GDP growth have a significant effect on Stock Price Index.. Toward the stock market, partially, there is negative significant impact of SBI interest rate, while there is positive significant impact of IDR to USD exchange rate. Meanwhile, both inflation and GDP growth has no partial effect on the stock price index (Lukisto \& Anastasia, 2014).

Based on the research question, the hypothesis in this study can be described as follows:

1. Is there any significant impact of each macroeconomics factor (Inflation, Interest Rate, Rupiah Exchange Rate) on the IDX Composite during COVID-19 pandemic?

2. Is there any significant impact of all macroeconomics factors simultaneously (Inflation, Interest Rates, Rupiah Exchange Rate) on the IDX Composite during COVID-19 pandemic?

3. Is there any significant impact of each macroeconomics factor (Inflation, Interest Rate, Rupiah Exchange Rate) on IDXFINANCE during the COVID-19 pandemic?

4. Is there any significant impact of all macroeconomics factors simultaneously (Inflation, Interest Rates, Rupiah Exchange Rate) on IDXFINANCE during the COVID-19 pandemic?

\section{Research Method}

Below are the detailed explanations about the research method, starting from the data until how the data are processed, including the detailed processing method.

\section{Data Type and Data Collection}

Quantitative data and secondary data will be used in this research. The data are collected from several sources namely Yahoo Finance, Investing.com (Investing, 2021), Bank Indonesia (Bank Indonesia, 2021), and JHU CSSE COVID-19 Data. Quantitative data is the data on a numeric scale which can be counted or compared (DeWitt Wallace Library, 2021) On the other hand, secondary data is the past data collected by an organization, government, institution, or any other larger party (Walgh, 2021).

\section{Population and Sample}

Population is defined as a whole group which the information will be obtained through, while sample means a part of a total population chosen through several methods (Banerjee \& Chaudhury, 2010). This study will use IDXFINANCE $\left(\mathrm{Y}_{1}\right)$, IDX Composite $\left(\mathrm{Y}_{2}\right)$, Indonesian inflation $\left(\mathrm{X}_{1}\right)$, USD to IDR exchange rate $\left(\mathrm{X}_{2}\right)$, BI Rate $\left(\mathrm{X}_{3}\right)$ and COVID-19 new cases $\left(\mathrm{X}_{4}\right)$ as the population. As for the sample, the monthly data of mentioned factors from March 2020 to June 2021, this leads the sampling method to use purposive sampling with those requirements. Purposive sampling is a sampling method which selects the data according to several requirements determined by the author or researcher.

\section{Data Analysis}

Multiple linear regression is one of linear regression models which analyzes the correlation between quantitative data to predict the dependent variable. Multiple linear regression is commonly utilized in 
several sectors, including financial, economics and business (Kutneer, et, all., 2005). In addition, R Programming is utilized in analyzing the data. Below is the equation of the multiple linear regression model (Dewi \& Suryanawa, 2014).

$$
Y_{i}=\alpha+\beta_{1} X_{1}+\beta_{2} X_{2}+\beta_{3} X_{3}+\beta_{4} X_{4}+\varepsilon
$$

$\alpha$ : Coefficient of the model $(0.05)$

$Y_{\mathrm{i}:}$ Dependent variable

$Y_{1:}$ IDXFINANCE

$Y_{2:}$ IDX Composite

$\beta_{\mathrm{i}}$ : Parameter of each independent variable

$\mathrm{X}_{\mathrm{i}}$ : Independent variable

$\mathrm{X}_{1}$ : Indonesian inflation

$\mathrm{X}_{2}$ : USD to IDR exchange rate

$\mathrm{X}_{3}$ : BI Rate

$\mathrm{X}_{4}$ : COVID-19 new cases

$\varepsilon$ : Residual error

Below are the hypotheses in determining which independent variable(s) impacts a dependent variable.

$\mathrm{H}_{0}$ : The independent variables $\left(\mathrm{X}_{1}, \mathrm{X}_{2}, \mathrm{X}_{4}, \mathrm{X}_{4}\right)$ has no impact toward the dependent variables $\left(\mathrm{Y}_{1}\right.$ or $\left.\mathrm{Y}_{2}\right)$

$\mathrm{H}_{1}$ : The independent variables $\left(\mathrm{X}_{1}, \mathrm{X}_{2}, \mathrm{X}_{4}, \mathrm{X}_{4}\right)$ has impact toward the dependent variables $\left(\mathrm{Y}_{1}\right.$ or $\left.\mathrm{Y}_{2}\right)$ with criteria:

Accept $\mathrm{H}_{0}$ if significance value $>\alpha(0.05)$

Reject $\mathrm{H}_{0}$ if significance value $<\alpha(0.05)$

Since we have 2 (two) dependent variables, all of the data analysis procedures will be done twice, the first one for the first dependent variable, IDXFINANCE $\left(\mathrm{Y}_{1}\right)$, and latter for the second dependent variable, IDX Composite $\left(\mathrm{Y}_{2}\right)$.

Descriptive Statistics

Descriptive statistics are used to help researchers in organizing and finding the measured behavior of the data (SAGE Publications, 2019). Mean, median, minimum and maximum will be used to be the descriptive statistics determinants.

\section{Classical Assumption Test}

Classical assumption test is understood to ensure whether the data are already in accordance with the BLUE (Best, Linear, Unbiased Estimator) criteria (Dewi \& Suryanawa, 2014). Below are the classical assumption tests.

\section{Normality Test}

Normality test is used to check whether the data's residuals are in normal distribution or not (Mardiatmoko, 2019). One of the most effective normality tests is the Shapiro-Wilk Test, which was found in 1965 (Razali $\&$ Wah, 2011). Shapiro-Wilk test will be implemented in testing the normality in this study. Below are the criteria in determining the normality.

For the significance value of $<\alpha(0.05)$, the residuals are not following the normal distribution (Mardiatmoko, 2019).

For the significance value of $>\alpha(0.05)$, the residuals are following the normal distribution (Mardiatmoko, 2019).

\section{Multicollinearity Test}

Multicollinearity test is used to check if there is any significant linear correlation between the independent variables (Mardiatmoko, 2019). Below are the criteria in determining the multicollinearity.

The criteria in determining the multicollinearity are that if VIF (Variance Inflation Factor) value is $<10$ and tolerance value $>0.1$, it determines that there is no multicollinearity. Otherwise, if one of even both of the criteria above is/are not satisfied, it means there is multicollinearity (Mardiatmoko, 2019).

Autocorrelation Test

Autocorrelation test is used to test if there is any correlation between the residual in lagged time (Mardiatmoko, 2019). The Durbin-Watson test will be utilized in the autocorrelation test since it is found to be better than other several autocorrelation tests (L'Esperance \& Taylor, 1974). Below are the criteria in determining the autocorrelation. 
The criteria in determining the autocorrelation are if the significance value of $<\alpha(0.05)$, there is autocorrelation. While if the significance value of $>\alpha(0.05)$, there is no autocorrelation.

Heteroscedasticity Test

Heteroscedasticity test is used to check whether there is an unmatched variant of the residuals in the data. Brerusch-Pagan test will be used in this study since it is still effective for non-high leverage data (Lyon \& Tsai, 1996). Below are the criteria in determining the heteroscedasticity.

The criteria in determining the heteroscedasticity are that if the significance value of $<\alpha(0.05)$, there is heteroscedasticity. While if the significance value of $>\alpha(0.05)$, there is no heteroscedasticity.

F-Test

F-test is used to check if the correlation between the independent variables toward the dependent variable simultaneously is detected or not. Below are the hypotheses in determining the F-test (Mardiatmoko, 2019). $\mathrm{H}_{0}$ : The independent variables $\left(\mathrm{X}_{1}, \mathrm{X}_{2}, \mathrm{X}_{3}, \mathrm{X}_{4}\right)$ has no simultaneous impact toward the dependent variables $\left(\mathrm{Y}_{1}\right.$ or $\left.\mathrm{Y}_{2}\right)$

$\mathrm{H}_{1}$ : The independent variables $\left(\mathrm{X}_{1}, \mathrm{X}_{2}, \mathrm{X}_{3}, \mathrm{X}_{4}\right)$ has simultaneous impact toward the dependent variables $\left(\mathrm{Y}_{1}\right.$ or $\mathrm{Y}_{2}$ )

Where the hypothesis criteria are accept $\mathrm{H}_{0}$ if significance value $>\alpha(0.05)$ and reject $\mathrm{H}_{0}$ if significance value $<\alpha(0.05)$.

T-test

T-test is used to check if the correlation between the independent variables toward the dependent variable partially is detected or not. Below are the hypotheses in determining the t-test (Mardiatmoko, 2019).

$\mathrm{H}_{0}$ : The independent variable $\left(\mathrm{X}_{1}, \mathrm{X}_{2}, \mathrm{X}_{3}\right.$, or $\left.\mathrm{X}_{4}\right)$ has no partial impact toward the dependent variables $\left(\mathrm{Y}_{1}\right.$ or $\mathrm{Y}_{2}$ )

$\mathrm{H}_{1}$ : The independent variables $\left(\mathrm{X}_{1}, \mathrm{X}_{2}, \mathrm{X}_{3}\right.$, or $\left.\mathrm{X}_{4}\right)$ has partial impact toward the dependent variables $\left(\mathrm{Y}_{1}\right.$ or $\mathrm{Y}_{2}$ )

Where the hypothesis criteria are accept $\mathrm{H}_{0}$ if significance value $>\alpha(0.05)$ and reject $\mathrm{H}_{0}$ if significance value $<\alpha(0.05)$

\section{$R$ Square}

$\mathrm{R}$ Square is utilized to measure the effectiveness percentage of significant impact of independent variables toward dependent variables (Mardiatmoko, 2019).

\section{Result and Discussion}

Below is the table that summarized the result of descriptive statistics for all of the depended and independent variables.

\begin{tabular}{lllllll}
\hline \multicolumn{7}{c}{ Table 1. Descriptive Statistics } \\
Statistical & Inflation & $\begin{array}{l}\text { Exchange } \\
\text { Rate }\end{array}$ & BI Rate & $\begin{array}{l}\text { COVID-19 } \\
\text { Case }\end{array}$ & IDXFINANCE & $\begin{array}{l}\text { IDX } \\
\text { Composite }\end{array}$ \\
\hline Minimum & 0.01320 & 14020 & 0.03500 & 1528 & 947.8 & 4539 \\
Median & 0.01545 & 14225 & 0.03500 & 125938 & 1222.1 & 5425 \\
Mean & 0.01719 & 14534 & 0.03906 & 136142 & 1192.7 & 5432 \\
Maximum & 0.02960 & 16300 & 0.04500 & 356569 & 1419.9 & 6242 \\
\hline
\end{tabular}

Source: Processed Data

As for the inflation it can be seen that the mean is 0.017 , which was affected due to the depression of purchasing power during the COVID-19. As for the exchange rate, the highest was at Rp 16,575.00 on March $23^{\text {rd }} 2020$. It was historically recorded that in the next period, the exchange rate dropped to around Rp 14,000 until June 2021. On the other hand, BI Rate also faced a decline to the level of 3.5\%, the Central Bank has also been already striving with all of the instruments' policies to stimulate the national economic recovery.

According to the Table 2, for the classical assumption test, in the F-Test on IDXFINANCE and IDX Composite, it is known that each F-Statistic value is 39.29 significant on alpha 0.000, and 64.91 significant on alpha 0,000 . It means that both models rejected $\mathrm{H}_{0}$ of overall test (F-test). It can be interpreted that simultaneously, inflation, exchange rate, BI Rate and COVID-19 case significantly impacted both IDXFINANCE and IDX Composite. On the other hand, coefficient determination values (R-Squared) for each dependent variable is 0.9108 and 0.9446 , this indicated that the impact of the independent variables toward dependent variables is contributed at $91.08 \%$ and $94.46 \%$. On the other hand, it can be seen that 
both model, IDXFINANCE and IDX Composite models, passed the classical assumption test such as normality test, multicollinearity test, heteroscedasticity test and autocorrelation test. Table 2 explains about it in more detail.

Table 2. Classical Assumption Test

\begin{tabular}{|c|c|c|}
\hline Variables & IDXFINANCE & IDX Composite \\
\hline F-test & $\begin{array}{l}\text { F-Statistic: } 39.29 \\
\text { Probability:1.88e-06 } \\
\text { Conclusion: Significant }\end{array}$ & $\begin{array}{l}\text { F-Statistic: } 64.91 \\
\text { Probability: } 1.404 \mathrm{e}-07 \\
\text { Conclusion: Significant }\end{array}$ \\
\hline Adj $R$-Squared & 0.9108 & 0.9446 \\
\hline Normality Test & $\begin{array}{l}0.6204 \\
\text { Data are normally distributed }\end{array}$ & $\begin{array}{l}0.7143 \\
\text { Data are normally distributed }\end{array}$ \\
\hline Multicollinearity Test & $\begin{array}{l}\text { Inflation } \\
\text { Tolerance:0.3018 } \\
\text { VIF:3.313 }\end{array}$ & $\begin{array}{l}\text { Inflation } \\
\text { Tolerance: } 0.3018 \\
\text { VIF: } 3.313\end{array}$ \\
\hline & $\begin{array}{l}\text { Exchange Rate } \\
\text { Tolerance: } 0.5528 \\
\text { VIF:1.808758 }\end{array}$ & $\begin{array}{l}\text { Exchange Rate } \\
\text { Tolerance: } 0.5528 \\
\text { VIF: } 1.808\end{array}$ \\
\hline & $\begin{array}{l}\text { BI Rate } \\
\text { Tolerance: } 0.222 \\
\text { VIF: } 4.487\end{array}$ & $\begin{array}{l}\text { BI Rate } \\
\text { Tolerance: } 0.222 \\
\text { VIF: } 4.487\end{array}$ \\
\hline & $\begin{array}{l}\text { COVID-19 New Case } \\
\text { Tolerance: } 0.364 \\
\text { VIF: } 2.744\end{array}$ & $\begin{array}{l}\text { COVID-19 New Case } \\
\text { Tolerance: } 0.364 \\
\text { VIF: } 2.744\end{array}$ \\
\hline Autocorrelation Test & $\begin{array}{l}0.3661 \\
\text { There is no autocorrelation }\end{array}$ & $\begin{array}{l}0.5493 \\
\text { There is no autocorrelation }\end{array}$ \\
\hline Heteroscedasticity Test & $\begin{array}{l}0.5583 \\
\text { There is no heteroscedasticity }\end{array}$ & $\begin{array}{l}0.7166 \\
\text { There is no heteroscedasticity }\end{array}$ \\
\hline
\end{tabular}

Furthermore, table 3 below summarized the result of t-test and multiple linear regression for IDXFINANCE.

Table 3. Coefficient of Multiple Linear Regression for IDXFINANCE

\begin{tabular}{lccc}
\hline \multicolumn{1}{c}{ Variables } & Coefficient & t-Statistic & Prob \\
\hline Intercept & $3.161 \mathrm{e}+03$ & 6.570 & $4.02 \mathrm{e}-05$ \\
Inflation & $6.598 \mathrm{e}+03$ & 1.483 & 0.166 \\
Exchange Rate & $-3.557 \mathrm{e}-02$ & -1.182 & -0.262 \\
BI Rate & $-4.053 \mathrm{e}+04$ & -5.984 & $9.13 \mathrm{e}-05$ \\
COVID-19 New Case & $1.337 \mathrm{e}-04$ & 0.742 & 0.473 \\
\hline
\end{tabular}

Source: Processed Data

Therefore, the multiple linear regression model obtained is

$$
\text { IDXFINANCE }=3161+6598 X_{1}-0.03557 X_{2}-40530 X_{3}+0.0001337 X_{4}+\varepsilon
$$

The constant value of 3161 with significant value $<0.05$ which is 0.00004 , indicates that if all dependent variables do not have any modification, the value of IDXFINANCE is 3161. The value of the inflation regression coefficient is 6598 with a significant alpha of 0.166 , meaning that inflation has no significant 
impact. The regression coefficient indicate that if inflation increases by one unit, IDXFINANCE increase by 6598 , when the others independent variables are constant. The value of the Exchange rate regression coefficient is -0.03557 with a significant alpha of 0.262 , meaning that inflation has no significant impact. The regression coefficient indicate that if the Exchange rate increases by one unit, IDXFINANCE will decline by 0.0355 when the others independent variables are constant. The value of the BI Rate regression coefficient is -40530 with a significant alpha of 0.00009 , meaning that BI Rate has significant impact. The regression coefficient indicate that if the BI Rate increases by one unit, IDXFINANCE will decline by 40530 when the others independent variables are constant. The value of the COVID-19 case regression coefficient is -0.0001 with a significant alpha of 0.473 , meaning that inflation has no significant impact. The regression coefficient indicate that if COVID-19 cases increase by one unit, IDXFINANCE will decline by 0.0001 when the others independent variables are constant.

Based on the results Table 3, the significant independent variable test (t-test), it is known that inflation has no significant impact on IDXFINANCE ( $\mathrm{H}_{0}$ of $\mathrm{t}$-test is accepted). This is because $\mathrm{t}_{\text {calculation }} 1.483<\mathrm{t}_{\text {table }} 1.66$ and the probability $0.166>0.05$. Furthermore, the result for the exchange rate, it is known that exchange rate has no significant impact on IDXFINANCE $\left(\mathrm{H}_{0}\right.$ of t-test is accepted). This is because $t_{\text {calculation }}-1.182$ $<\mathrm{t}_{\text {table }} 1.66$ and the probability $0.262>0.05$. Then, the result for the BI Rate, it is known that BI rate has a significant negative impact on IDXFINANCE ( $\mathrm{H}_{0}$ of $\mathrm{t}$-test is rejected). This is because $\mathrm{t}_{\text {calculation }}-5.984<$ $\mathrm{t}_{\text {table }} 1.66$ and the probability $0.000<0.05$. Meanwhile, the result for the COVID-19 cases, it is known that COVID-19 cases have no significant impact on IDXFINANCE $\left(\mathrm{H}_{0}\right.$ of t-test is accepted). This is because $\mathrm{t}_{\text {calculation }} 0.742<\mathrm{t}_{\text {table }} 1.66$ and the probability $0.473>0.05$.

The next, table 4 below summarized the result of t-test and multiple linear regression for IDXFINANCE.

Table 4. Coefficient of Multiple Linear Regression for IDX Composite

\begin{tabular}{llll}
\hline Variables & Coefficient & t-Statistic & Prob \\
\hline Intercept & $1.390 \mathrm{e}+04$ & 9.927 & $7.96 \mathrm{e}-07$ \\
Inflation & $3.919 \mathrm{e}+04$ & 3.027 & 0.0115 \\
Exchange Rate & $-2.436 \mathrm{e}-01$ & -2.780 & 0.0179 \\
BI Rate & $-1.464 \mathrm{e}+05$ & -7.428 & $1.31 \mathrm{e}-05$ \\
COVID-19 New & $8.587 \mathrm{e}-04$ & 1.638 & 0.1296 \\
Case & & & \\
\hline
\end{tabular}

Source: Processed Data

According to Table 4, the multiple linear regression model obtained is

$$
\text { IDXFINANCE }=13900+39190 \mathrm{X}_{1}-0.2436 \mathrm{X}_{2}-146400 \mathrm{X}_{3}-0.0008587 \mathrm{X}_{4}+\varepsilon
$$

The constant value of 13900 with a significant value $<0.05$ which is 0.0000007 , indicates that if all dependent variables do not have any modification, the value of IDX Composite is 13,900. The value of the inflation regression coefficient is 39190 with a significant alpha of 0.0115 , meaning that inflation has a significant impact on IDX Composite. The regression coefficient indicate that if inflation increases by one unit, IDX COMPOSITE will increase by 39190 when the others independent variables are constant. The value of the Exchange rate regression coefficient is -0.2436 with a significant alpha of 0.0179 , meaning that the Exchange rate has a significant impact. The regression coefficient indicate that if inflation increases by one unit, IDX Composite will decline by 0.2436 when the others independent variables are constant. The value of the BI Rate regression coefficient is -146400 with a significant alpha of 0.00001 , meaning that BI Rate has a significant impact. The regression coefficient indicate that if the BI Rate increases by one unit, IDX Composite will decline by 146400 when the others independent variables are constant. The value of the COVID-19 case regression coefficient is 0.0008587 with a significant alpha of 0.1296 , meaning that COVID-19 has a significant impact. The regression coefficient indicate that if COVID-19 cases increase by one unit, IDX Composite will increase by 0.0008587 when the others independent variables are constant. Based on the results Table 4, the significant independent variable test (t-test), it is known that inflation has a positive significant impact on IDX Composite $\left(\mathrm{H}_{0}\right.$ of $\mathrm{t}$-test is rejected). This is because $\mathrm{t}_{\text {calculation }} 3.027>$ $\mathrm{t}_{\text {table }} 1.66$ and the probability $0.0115<0.05$. Furthermore, the result for the exchange rate, it is known that exchange rate has a negative significant impact on IDX Composite $\left(\mathrm{H}_{0}\right.$ of $\mathrm{t}$-test is rejected). This is because $\mathrm{t}_{\text {calculation }}-2.780<\mathrm{t}_{\text {table }} 1.66$ and the probability $0.0179<0.05$. Then, the result for the BI Rate, it is known that $\mathrm{BI}$ rate has a significant negative impact on IDX Composite $\left(\mathrm{H}_{0}\right.$ of $\mathrm{t}$-test is rejected $)$. This is because 
$\mathrm{t}_{\text {calculation }}-7.428<\mathrm{t}_{\text {table }} 1.66$ and the probability $0.000<0.05$. Meanwhile, the result for the COVID-19 cases, it is known that COVID-19 cases have no significant impact on IDXFINANCE ( $\mathrm{H}_{0}$ of t-test is accepted). This is because $t_{\text {calculation }} 1.63<t_{\text {table }} 1.66$ and the probability $0.1296>0.05$.

The results showed that the inflation rate, exchange rate, BI rate and COVID-19 cases together had a significant impact on IDXFINANCE and IDX Composite. This capital market indicator can fluctuate in line with changes in existing macroeconomics assumptions. This capital market indicator can fluctuate in line with changes in existing macroeconomics assumptions. Consequently, the investor must be able to understand the behavioral patterns of stock price movements and the IDX Composite implications of internal and external factors in a country that can affect capital markets, before investing.

\section{Conclusion and Implications}

This study has implemented multiple linear regression to examine the impact of inflation, BI rate, exchange rate and COVID-19 monthly cases toward IDXFINANCE and IDX Composite as the dependent variables, respectively. According to the results obtained above, we understand that for the period of March 2020 until June 2021, as for IDX Composite, it was highly significantly impacted by BI Rate, negatively. As well as Indonesian inflation and USD to IDR exchange rate significantly impacted IDX Composite, consecutively positively and negatively. Thus, COVID-19 monthly cases in Indonesia did not impact IDX Composite. As for IDXFINANCE, it was only highly significantly impacted by BI Rate, negatively. Otherwise, USD to IDR exchange rate, Indonesian inflation, and COVID-19 monthly cases in Indonesia did not impact IDXFINANCE at all. Simultaneously, using the F-test, all of the mentioned macroeconomics variables, USD to IDR exchange rate, Indonesian inflation, BI rate, and COVID-19 monthly cases in Indonesia, impacted both IDX Composite and IDXFINANCE. Hopefully this research can be an additional resource for the investors and traders in making decisions when they would like to enter the stock market, by also taking the mentioned macroeconomics factors into consideration.

For further researchers, in this case, the data used by the author is publication data so that it is data that has been processed. Therefore, it is hoped that future researchers can get data from the main sources and more comprehensive with measuring tools which have been determined by the Service Authority Finance as an Institution that responsible for the financial institutions in Indonesia. Also for the period, we hope the next researcher can use data starting from pandemic COVID-19 until the case of COVID-19 is declined. Also, for the variable, it is hoped that in the next research the independent and dependent variables will be more developed compare to the variables in this study. For practitioners, should be able to see the effect of macroeconomic factors on the ups and downs of IDXFINANCE and IDX Composite. Thus, it can minimize the level of losses that may occur in the future.

\section{References}

Banerjee, A., \& Chaudhury, S., (2010) Statistics without tears: Populations and samples Industrial Psychiatry Journal 19(1) 60-

\section{PMC3105563}

Bank Indonesia. (2021) Data Inflasi [dataset] https://wwwbigoid/id/statistik/indikator/datainflasiaspx

Bursa Efek Indonesia. (2021). IDX Stock Index Handbook v12. https://wwwidxcoid/media/9816/idxstock-index- handbook-v12-_-januari-2021pdf

Bursa Efek Indonesia. (2021). Fact Sheet Index https://wwwidxcoid/data-pasar/laporan statistik/factsheet-indeks/

Dewi, N.,K., S., L., \& Suryanawa, I., K., (2014) Pengaruh Struktur Kepemilikan, Manajerial, Leverage, and Financial Distress terhadap Konservatisme Akuntansi E-Jurnal Akuntansi Universitas Udayana 71 (2014) ISSN: 2302-8556

DeWitt Wallace Library (2021) Qualitative vs Quantitative Data https://libguidesmacalesteredu/cphp?g=527786\&p=3608639

Ilham, K., R., and Nyoman S., I., A., (2019) The Influence of World Stock Index, BI Rate and FED Rate through IHSG on Exchange Rates in Indonesia for the Period of 2006-2015 RJOAS, 9(93) September 2019 1018551/rjoas2019- 0923

Investing. (2021) USD/IDR Historical Data [dataset] https://wwwinvestingcom/currencies/usdidrhistorical-data

John Hopkins University Centre for Systems Science and Engineering 2021 COVID-19 [dataset]. https://github.com/cssegisanddata/covid-19

Kewal, S., S., (2012) Pengaruh inflasi, suku bunga, kurs, dan pertumbuhan PDB terhadap indeksharga saham gabungan Jurnal economia, 8(1), 53-64

Kutner, M., H., et, all. (2005) Applied Linear Statistical Model (New York: McGraw-Hill Irwin) p 2 
L'Esperance, W. \& Taylor, D. (1974) The Power of Four Tests of Autocorelation in the Linear Regression Model Journal of Econometrics 3 p 1-21

Lukisto, J, \& Anastasia, N. (2014) Dampak Makroekonomi Terhadap Indeks Harga Saham Sektor Properti Di Indonesia Periode Tahun 1994-2012 Jurnal Analisa, 3(2), 1-5

Lyon, J. D., \& Tsai, C. L., (1996) A Comparison of Tests Heteroscedasticity Journal of the Royal Statistical Society Series D (The Statistician) 45(3) p 337-349

Mardiatmoko, G., (2019) The Importance of the Classical Assumption Test in Multiple Linear Regression Analysis (A Case Study of the Preparation of the Allometric Equation of Young Wallnuts) BAREKENG: Jurnal Ilmu Terapan dan Matematika 14(3) E-: 2615-3017

Megawati, N., \& Salim, M., N., (2018) Pengaruh Variabel Makroekonomi terhadap Indeks Harga Saham Gabungan (IHSG) Media Ekonomi 2647 1025105/mev26i15163

Nuraini, R. (2020 March 2) Kasus Covid-19 Pertama Masyarakat Jangan Panik Indonesiagoid. https://indonesiagoid/narasi/indonesia-dalam-angka/ekonomi/kasus-covid-19-pertamamasyarakatjangan-panik

Nurdin, A., A., et, all. (2020) Pola Kinerja Perusahaan Sesudah Merger dan Akuisisi serta Analisis Terhadap Faktor-Faktor yang Mempengaruhinya Jurnal Riset Akuntansi dan Keuangan, 8(2), 431-446

Oktarina, D (2016) Pengaruh beberapa indeks saham global dan indikator makroekonomi terhadap pergerakan IHSG Journal of Business and Banking, 5(2), 163-182

Parkin, M. (2012). Economic (Boston: Pearson Education Inc) p2

Razali, N., M., and Wah, Y.,B., (2011) Power Comparison of Shapiro-Wilk, Kolmogorov Smirnoff, Lilliefors and Anderson-Darling tests Journal of Statistical Modelling and Analytics 2 p 2133

SAGE Publications, Inc (2019) Introduction and Descriptive Statistics $\mathrm{p}$ 5-6 https://ussagepubcom/sites/default/files/upm- assets/90578_book_item_90578pdf

Walgh, S., (2021) Primary \& Secondary Data Definitions Benedictine University https://researchguidesbenedu/cphp?g=282050\&p=4036581

Yahoo! Finance 2021 Jakarta Composite Index (^JKSE) [dataset]. https://financeyahoocom/quote/\%5EJKSE?p=^JKSE\&tsrc=fin-srch 